\title{
Design and evaluation of a bioadhesive film for transdermal delivery of propranolol hydrochloride
}

\author{
BAZIGHA K. ABDUL RASOOL ${ }^{1, *}$ \\ UDAY S. AZIZ ${ }^{2}$ \\ OMAR SARHEED ${ }^{3}$ \\ ALAA A. ABDUL RASOOL ${ }^{4}$ \\ 1 Department of Pharmaceutics and \\ Pharmacy Practice, Dubai Pharmacy \\ College, Dubai, UAE \\ 2 Department of Pharmaceutics \\ College of Pharmacy, University \\ of Basra, Basra, Iraq \\ ${ }^{3}$ Department of Pharmaceutics, RAK \\ College of Pharmaceutical Sciences \\ Ras Al-Khaimah Medical and Health \\ Sciences University, Ras Al-Khaimah \\ $U A E$ \\ ${ }^{4}$ College of Pharmacy, University of \\ Baghdad, Baghdad, Iraq
}

\begin{abstract}
The objective of the study was to develop a suitable transdermal delivery system for propranolol hydrochloride (PPL) via employing chitosan as a film former. Drug concentration uniformity, thickness, moisture uptake capacity and skin bioadhesion of the films were characterized. The effects of chitosan and PPL concentration and different penetration enhancers on the release and permeation profiles from the films were investigated. Skin irritation of the candidate film was evaluated. Chitosan film (PPL $2 \mathrm{mg} \mathrm{cm}{ }^{-2}$, chitosan $2 \%, \mathrm{~m} / \mathrm{m}$, cineol $10 \%, \mathrm{~m} / \mathrm{m}$ ) was found nonirritant and achieved $88.2 \%$ release after 8 hours in phosphate buffer. Significant high $(p<0.001)$ permeation of PPL through rat skin was obtained using this film compared to the film without enhancer (about 8 times enhancement factor), making it a promising transdermal delivery system for PPL.
\end{abstract}

Keywords: transdermal delivery, propranolol hydrochloride, chitosan film, enhancers

Oral administration is one of the most convenient ways that are acceptable for patients, useful and suitable for drugs that are not subjected to intestinal and/or hepatic first-pass metabolism (1). However, there are several shortcomings that should be overcome to achieve efficient drug therapy: the intestinal and/or hepatic first-pass elimination, high variance in bioavailability, difficulty in long-term and rate-regulated absorption and impossibility of arbitrary drug input and its interruption (2). Transdermal route is one of the potential alternative routes that may bypass undesirable characteristics of oral administration. Propranolol, a $\beta$-blocker, has short biological half-life and is extensively subjected to hepatic first-pass metabolism (3). Propranolol $\cdot \mathrm{HCl}\left(M_{\mathrm{r}} 135\right.$, water solubility $>150 \mathrm{mg} \mathrm{mL}^{-1}$ ) can be a potential candidate for transdermal use. Recently, development of transdermal drug delivery systems (TDDS) has been focused on the for-

*Correspondence; e-mail: bazigharasool@yahoo.com; bazigha_rasool@hotmail.com 
mulation part to achieve the desirable constant rate of drug penetration into the systemic circulation. One way to design a TDDS is by employing polymers as matrices or membranes controlling the release of drugs (4). On the other hand, the impermeability of human skin is still a fundamental problem to be overcome for the therapeutic use of TDDS (5). Although many physical approaches such as ultrasound, iontophoresis and electroporation have been proposed to surmount the stratum corneum, the main barrier for transdermal drug absorption (2), chemical approaches such as the utilization of enhancers might be the easiest way to patch preparations. Among many enhancers, terpenes have been extensively investigated for their clinical use as penetration enhancers and are generally regarded as safe (GRAS) by FDA. It is suggested that terpenes increase drug diffusivity in the skin by disrupting the intercellular lipid packing in the horny layer (2). Considering the balance between efficiency and toxicity, several terpenes may be promising enhancers for clinical use (6).

In the present study, a suitable film preparation of propranolol hydrochloride (PPL) has been developed by employing chitosan polymer as a film former, and glycerine as a plasticizer. Furthermore, in order to improve the penetration of PPL, enhancers including terpenes (menthol and cineole), propylene glycol (PG), surfactants [sodium lauryl sulphate (SLS), Tween ${ }^{\circledR} 80$ and benzalkonium chloride (BZK)] and oleic acid (OA) were employed. Physicochemical characterization of the films was done. In vitro release and permeation profiles of PPL from film preparations were examined.

\section{EXPERIMENTAL}

\section{Materials}

Chitosan (medium molecular mass), PPL, HPLC-grade acetonitrile, oleic acid, potassium dihydrogen orthophosphate, disodium hydrogen orthophosphate and phosphate buffer saline (PBS) tablets ( $\mathrm{pH}$ 7.4) were all purchased from Sigma-Aldrich (UK). Diethyl ether, sodium hydroxide, sodium lauryl sulphate, glycerol and potassium chloride were obtained from BDH Chemicals Ltd. (UK). Silica gel was bought from Merck (Germany). Cineole, menthol and benzalkonium chloride were from Fluka AG (UK). HPLC grade glacial acetic acid was obtained from Fisons Scientific Equipment (UK). Double distilled, de-ionised water was used throughout.

\section{Preparation of PPL-chitosan film formulation}

Chitosan film was prepared by dissolving $1 \mathrm{~g}$ of chitosan in $100 \mathrm{~mL}$ of acetic acid $(1 \%, m / V)$ at room temperature. Glycerine was incorporated at a concentration of $10 \%$ $(\mathrm{m} / \mathrm{m})$ of the total dry mass of the polymer, as plasticizer. The resultant mixture was left under stirring for $1 \mathrm{~h}$ until a viscous chitosan gel was formed. PPL at a predetermined loading $\left(\mathrm{mg} \mathrm{cm}^{-2}\right)$ and different enhancer concentrations $(\%, \mathrm{~m} / \mathrm{m})$ was dissolved and added to the gel. The viscous gel was left to stand until all air bubbles had disappeared. The final solution was spread on a clean dry glass plate in a dust-free atmosphere and dried at $50{ }^{\circ} \mathrm{C}$ for $24 \mathrm{~h}$ or at $37^{\circ} \mathrm{C}$ for $48 \mathrm{~h}$. The dry film obtained was peeled off, wrapped in aluminium foil and stored in a well closed container at room temperature until evaluation (7). 


\section{Film characterization}

Film thickness. - The thickness of films was measured at three different spots using a micrometer (Mitutoyo Co., Japan) and mean values were calculated (Table I).

Determination of drug in the film. - A known mass of chitosan ( $1 \mathrm{~g})$ film was dissolved in acetic acid $(2 \%, m / V)$ up to $100 \mathrm{~mL}$. Sample was filtered through membrane filter $0.45 \mu \mathrm{m}$. The concentration of PPL was measured at $290 \mathrm{~nm}$ by Cintra 5, UV spectrophotometer (GBC Scientific equipment, Australia). Measurements were taken against a blank solution, which was prepared by repeating the former procedure on blank film (chitosan film without drug).

Moisture uptake. - After keeping them $\left(4 \mathrm{~cm}^{2}\right)$ in desiccator with silica gel for 24 hours, the films were weighed. The films were then transferred to another desiccator containing saturated $\mathrm{NaCl}$ solution (relative humidity $75 \%$ ) at $25^{\circ} \mathrm{C}$. After equilibrium was achieved, the films were taken out and weighed. Moisture uptake capacity (MUC) was calculated (8) (Table I).

In vitro bioadhesive strength measurement. - The bioadhesive strength of PPL films was evaluated by employing a method described by Peh and Wong (7) using a texture analyzer (TA.XT2, Stable Micro System, UK) and adjusted automatically by the same computer software.

\section{In vitro release study}

The release of PPL was tested with a paddle type USP dissolution apparatus (Copley Scientific, UK) at $37{ }^{\circ} \mathrm{C}$. The film was cut into a circle with an area of $3.14 \mathrm{~cm}^{2}$ and sandwiched between double-sided sieves (as a weight). The film with the weight was placed in a glass vessel filled with $500 \mathrm{~mL}$ of phosphate buffer ( $\mathrm{pH}$ 7.4). The rotating speed of the paddle was $50 \mathrm{rpm}$. The sample solutions $(5 \mathrm{~mL})$ were removed through a syringe filter at predetermined time intervals. The withdrawn volume was replaced by the same volume of phosphate buffer to maintain its constant volume and sink conditions (9). The concentration of PPL was determined at $290 \mathrm{~nm}$.

\section{In vitro skin permeation}

Preparation of skin membranes. - The study was approved by the Research Ethics Committee of the College of Pharmacy, University of Baghdad, Iraq.

Male Wistar rats weighing approximately 150-200 g were sacrificed by ether inhalation. The abdominal skin was lightly shaved with an electrical clipper, defatted by wiping it with a cotton tip soaked in diethyl ether and kept in phosphate buffer $\mathrm{pH} 7.4$ for $1 \mathrm{~h}$. The skin was either used immediately or frozen $\left(-20^{\circ} \mathrm{C}\right)$ until ready for use.

PPL permeation study. - Rat skin obtained previously was mounted in Franz diffusion cells (Transdermal tester HDT 10, Copley Scientific, UK). The permeation area of the cell was $3.14 \mathrm{~cm}^{2}$. The donor compartment was left open and wrapped with cellophane to prevent film contamination from the atmosphere; the receptor chamber was filled with $17.7 \mathrm{~mL}$ of phosphate buffer $\mathrm{pH} 7.4$, magnetically stirred at $600 \mathrm{rpm}$ and ther- 
mostated at $37^{\circ} \mathrm{C}$. At predetermined periods of time, samples were taken from the receptor solution and analyzed for PPL content by HPLC.

The HPLC system consisted of a model LC-6A HPLC pump (Shimadzu, Japan) and a UV detector (SPD-6A, Shimadzu) set at $289 \mathrm{~nm}$. Analytical column was Inertsil ODS-3 $\left(\mathrm{C} 18,250 \times 4.6 \mathrm{~mm}\right.$, GL Sciences, Japan). The mobile phase was $\mathrm{CH}_{3} \mathrm{CN}\left(20 \mathrm{mmol} \mathrm{L}^{-1}\right)$ : $\mathrm{NH}_{4} \mathrm{Cl}(0.05 \%)$ phosphoric acid $(1: 1: 1, V / V / V)$. The flow rate was set at $1 \mathrm{~mL} \mathrm{~min}^{-1}(8)$. Each point on the standard curve was mean \pm SD of three readings. RSD for standard curves ranged from 0.1 to $18.7 \%$, and $R^{2}$ was higher than 0.998 .

Data of the skin permeation study was analyzed using two kinetic models, viz. the first-order rate kinetics where the rate of drug permeation is concentration-dependent and Higuchi model (10) which describes the release of drugs from an insoluble matrix where the cumulative amount of the permeated drug per unit area is proportional to the square root of time as follows:

$$
Q=2 c_{o}\left(\frac{D t}{\pi}\right)^{1 / 2}
$$

where $c$ is the initial drug concentration in the donor compartment, $Q$ is the cumulative amount of the drug released at time, $t$ and $D$ is the diffusion coefficient.

\section{Primary skin irritation}

Three preparations were evaluated for their skin irritation, namely, blank film (chitosan, $2 \%, \mathrm{~m} / \mathrm{m}$ ), control film (PPL, $2 \mathrm{mg} \mathrm{cm}^{-2}$, chitosan, $2 \%, \mathrm{~m} / \mathrm{m}$ ) and the candidate film (PPL, $2 \mathrm{mg} \mathrm{cm}^{-2}$, chitosan, $2 \%, \mathrm{~m} / \mathrm{m}$ cineole, $10 \%, \mathrm{~m} / \mathrm{m}$ ) in comparison with histamine (a substance of known irritancy for the purpose of calibration). The test was performed according to the reported method (11).

\section{Statistical analysis}

Results are expressed as the mean \pm SD of at least three experiments. Analysis of variance (ANOVA) was used to test the statistical significance of the differences between groups.

\section{RESULTS AND DISCUSSION}

\section{Film properties}

Estimation of the drug concentration at different points of chitosan films indicated uniform distribution of PPL throughout the film of 96.1-100.7 \% (Table I and II). Chitosan concentration significantly $(p<0.05)$ increased the film thickness and decreased the MUC. However, PPL loading tended to thicken the film and increased the moisture uptake significantly $(p<0.05)$, except for $3 \mathrm{mg} \mathrm{cm}^{-2}$, PPL loading for which moisture uptake were capacity changed slightly (Table I). 
B. K. A. Rasool et al.: Design and evaluation of a bioadhesive film for transdermal delivery of propranolol hydrochloride, Acta Pharm. 61 (2011) 271-282.

Table I. Physicochemical properties of PPL film formulations

\begin{tabular}{ccccc}
\hline $\begin{array}{c}\text { Chitosan } \\
(\%, m / m)\end{array}$ & $\begin{array}{c}\text { PPL } \\
\left(\mathrm{mg} \mathrm{cm}^{-2}\right)\end{array}$ & $\begin{array}{c}\text { Drug distribution } \\
(\%)^{\mathrm{a}}\end{array}$ & $\begin{array}{c}\text { Thickness } \\
(\mathrm{mm})^{\mathrm{a}}\end{array}$ & $\begin{array}{c}\text { MUC } \\
(\%)^{\mathrm{a}}\end{array}$ \\
\hline 1 & 2 & $100.4 \pm 2.5$ & $0.30 \pm 0.10$ & $20.1 \pm 1.3$ \\
2 & 1 & $97.7 \pm 1.0$ & $0.36 \pm 0.05$ & $13.4 \pm 3.2$ \\
2 & 2 & $99.6 \pm 3.3$ & $0.50 \pm 0.09$ & $18.9 \pm 5.4$ \\
2 & 3 & $100.5 \pm 8.5$ & $0.61 \pm 0.08$ & $19.6 \pm 3.4$ \\
3 & 2 & $98.6 \pm 5.5$ & $0.60 \pm 0.12$ & $12.5 \pm 4.8$ \\
4 & 2 & $98.9 \pm 6.9$ & $0.70 \pm 0.06$ & $8.80 \pm 1.9$ \\
\hline
\end{tabular}

a Mean $\pm \mathrm{SD}, n=3$.

Enhancers showed significant increase $(p<0.05)$ in MUC compared to the control film (Table II). Cineol $10 \%, \mathrm{~m} / \mathrm{m}$, showed the highest increment in film MUC. The reason for this increment still needs to be investigated. However, propylene glycol can absorb moisture from the environment because of its humectant ability.

\section{In vitro bioadhesion strength}

Table III presents the data of adhesiveness and work of adhesion 12 obtained from the texture analyzer for different chitosan films: blank film (chitosan $2 \%, \mathrm{~m} / \mathrm{m}$ ), control film (PPL $2 \mathrm{mg} \mathrm{cm}^{-2}$, chitosan $2 \%, \mathrm{~m} / \mathrm{m}$ ) and the candidate film (PPL $2 \mathrm{mg} \mathrm{cm}^{-2}$, chitosan $2 \%, \mathrm{~m} / \mathrm{m}$, cineole $10 \%, \mathrm{~m} / \mathrm{m}$ ). There were no significant differences in either adhesiveness or work of adhesion among the tested chitosan films. However, the blank film showed the highest adhesiveness and work of adhesion. All the prepared films were applied on excised rat skin in vitro for 8 hours during permeation studies and it was found that they firmly attached to the skin, indicating good adhesion properties for clinical use.

\section{Release study}

PPL release was found to be affected by chitosan concentration in the film. It decreased significantly $(p<0.05)$ as the concentration of chitosan, film forming agent, increased in the film (Fig. 1a). The best drug release was obtained with $2 \%(\mathrm{~m} / \mathrm{m})$ of chitosan which was $51.2 \%$ at the end of the run (after 8 hours). This effect is the same as that obtained by Amnuaikit et al. (8), who studied the in vitro release profile of PPL from transdermal films containing ethyl cellulose and polyvinyl pyrrolidine as film former.

The effect of PPL concentration on its release from chitosan film was studied by employing three concentrations $\left(1,2\right.$ and $\left.3 \mathrm{mg} \mathrm{cm}^{-2}\right)$ in chitosan $2 \%(\mathrm{~m} / \mathrm{m})$ as the film former. It was found that increasing the loading of PPL in the film from 1 to $2 \mathrm{mg} \mathrm{cm}^{-2}$ resulted in a significant increase $(p<0.05)$ of total drug release percentage from $33.4 \%$ to $51.2 \%$, respectively (Fig. 1b). Other researchers also reported that increasing the amount of PPL dispersed in the film would increase membrane porosity, leading to a greater, release of the drug (8). 
B. K. A. Rasool et al.: Design and evaluation of a bioadhesive film for transdermal delivery of propranolol hydrochloride, Acta Pharm. 61 (2011) 271-282.

However, the results could be explained on the basis that increasing PPL concentration enhanced the film MUC (Table I) and consequently increased the PPL solubility and its release from the film.

Table II. Physicochemical properties of PPL film formulations with different enhancers

\begin{tabular}{|c|c|c|c|}
\hline Enhancers $(\% \mathrm{~m} / \mathrm{m})$ & PPL content $(\%)^{\mathrm{a}}$ & Thickness $(\mathrm{mm})^{\mathrm{a}}$ & $\operatorname{MUC}(\%)^{\mathrm{a}}$ \\
\hline Control film $2 \mathrm{mg} \mathrm{cm}^{-2}$ & $99.6 \pm 3.3^{b}$ & $0.50 \pm 0.09$ & $18.9 \pm 5.4$ \\
\hline \multicolumn{4}{|l|}{ PG } \\
\hline 5 & $98.8 \pm 6.1$ & $0.53 \pm 0.05$ & $19.7 \pm 2.3$ \\
\hline 10 & $100.3 \pm 2.9$ & $0.60 \pm 0.02$ & $23.5 \pm 1.1$ \\
\hline 15 & $96.6 \pm 9.1$ & $0.64 \pm 0.03$ & $23.1 \pm 2.9$ \\
\hline \multicolumn{4}{|l|}{ Menthol } \\
\hline 5 & $97.9 \pm 1.3$ & $0.43 \pm 0.09$ & $20.1 \pm 8.1$ \\
\hline 10 & $99.5 \pm 2.3$ & $0.53 \pm 0.06$ & $20.1 \pm 2.5$ \\
\hline \multicolumn{4}{|l|}{ Cineole } \\
\hline 5 & $99.6 \pm 4.5$ & $0.50 \pm 0.31$ & $25.6 \pm 2.6$ \\
\hline 10 & $98.7 \pm 4.9$ & $0.60 \pm 0.07$ & $26.8 \pm 1.9$ \\
\hline \multicolumn{4}{|l|}{ PG $10 \%+$ cineole } \\
\hline 5 & $100.7 \pm 3.1$ & $0.55 \pm 0.02$ & $21.1 \pm 1.3$ \\
\hline 10 & $96.3 \pm 1.2$ & $0.53 \pm 0.02$ & $24.1 \pm 1.6$ \\
\hline \multicolumn{4}{|l|}{ PG $10 \%+$ menthol } \\
\hline 5 & $96.5 \pm 6.5$ & $0.60 \pm 0.03$ & $20.4 \pm 6.3$ \\
\hline 10 & $99.1 \pm 7.3$ & $0.53 \pm 0.08$ & $24.0 \pm 5.4$ \\
\hline \multicolumn{4}{|l|}{ SLS } \\
\hline 2.5 & $98.1 \pm 3.2$ & $0.60 \pm 0.11$ & $19.1 \pm 4.8$ \\
\hline 5 & $100.1 \pm 3.1$ & $0.63 \pm 0.12$ & $19.9 \pm 3.2$ \\
\hline \multicolumn{4}{|l|}{ BZK } \\
\hline 1 & $99.5 \pm 6.4$ & $0.51 \pm 0.16$ & $20.2 \pm 4.7$ \\
\hline 2.5 & $96.9 \pm 2.4$ & $0.53 \pm 0.06$ & $23.1 \pm 7.3$ \\
\hline 5 & $97.5 \pm 3.1$ & $0.53 \pm 0.05$ & $24.9 \pm 1.4$ \\
\hline \multicolumn{4}{|l|}{ Tween $^{\circledR} 80$} \\
\hline 1 & $99.9 \pm 1.6$ & $0.51 \pm 0.34$ & $21.5 \pm 2.6$ \\
\hline 2.5 & $100.0 \pm 2.9$ & $0.52 \pm 0.13$ & $23.1 \pm 3.1$ \\
\hline 5 & $96.1 \pm 1.1$ & $0.52 \pm 0.12$ & $24.9 \pm 2.8$ \\
\hline \multicolumn{4}{|l|}{ Oleic acid } \\
\hline 1 & $96.7 \pm 1.2$ & $0.50 \pm 0.08$ & $20.1 \pm 1.8$ \\
\hline 5 & $98.8 \pm 0.8$ & $0.51 \pm 0.09$ & $25.1 \pm 2.1$ \\
\hline
\end{tabular}

a Mean $\pm \mathrm{SD}, n=3$.

b $2 \mathrm{mg}$ PPL $\mathrm{cm}^{-2}$.

MUC moisture uptake capacity. 
a)

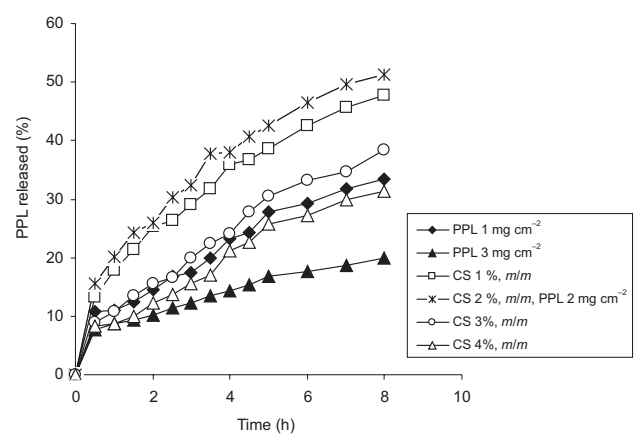

b)

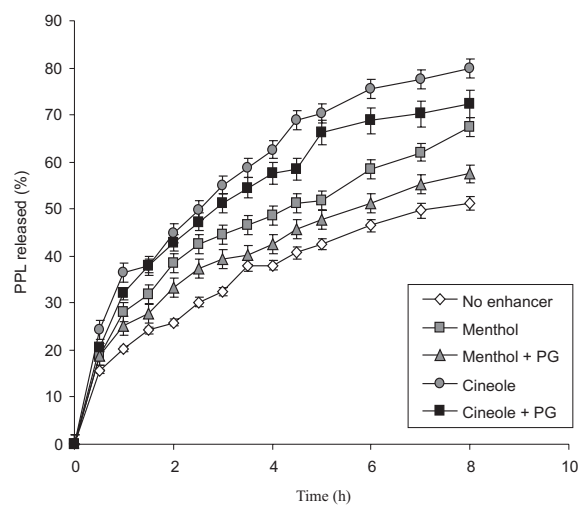

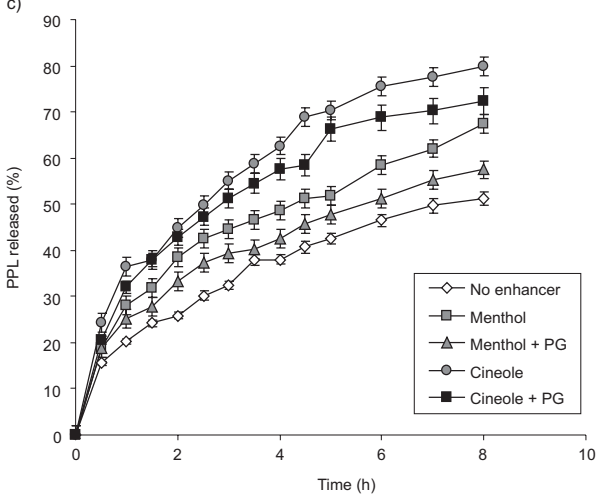

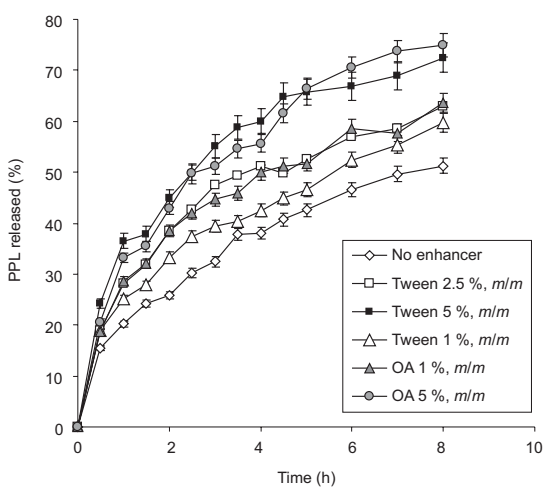

Fig. 1. Effect of: a) chitosan and PPL concentrations, b) terpenes $(5 \%, \mathrm{~m} / \mathrm{m})$, c) terpenes $(10 \%, \mathrm{~m} / \mathrm{m})$, d) Tween 80 and oleic acid on PPL release profile from chitosan film preparations in phosphate buffer ( $\mathrm{pH}$ 7.4). Results are expressed as the mean with the bars showing SD values of three different experiments.

The increment of propylene glycol from 5 to $10 \%(\mathrm{~m} / \mathrm{m})$ in the chitosan film significantly enhanced $(p<0.05)$ the in vitro release of PPL. $65.0 \%$ and $70.4 \%$ of PPL was released during $8 \mathrm{~h}$ from the films containing 5 and $10 \%$ PG, respectively, compared to $51.2 \%$ released from the film without enthancer. However, a significant decrease in PPL release $(31.0 \%)$ was obtained with propylene glycol $15 \%(\mathrm{~m} / \mathrm{m})$. Larger amount of water absorbed into the film by propylene glycol would contribute to the more rapid release of the drug from the film. On the other hand, the same humectants' property at higher concentrations may increase the viscosity of the film, resulting in slow drug release (13).

Moreover, addition of terpenes at a concentration of $5 \%(\mathrm{~m} / \mathrm{m})$ tended to a significant increase $(p<0.05)$ in PPL release profile while terpenes $10 \%(\mathrm{~m} / \mathrm{m})$ showed even 
higher increase, as shown in Figs. $1 b$ and c. Hence, the increase in PPL release could be correlated with the increase in MUC as enhancer concentration increased (Table II).

PPL in vitro release after $8 \mathrm{~h}$ using SLS 2.5 and $5 \%(\mathrm{~m} / \mathrm{m})$ was $36.4 \%$ and $42.0 \%$, respectively, compared to chitosan film without enhancer $(51.2 \%)$. The decrease in PPL release might be attributed to the ability of the anionic surfactant, SLS, to form complexes with the cationic drug via its negative charge. The presumed SLS-PPL complex may show less solubility than the free PPL and consequently less release into the dissolution medium (13). Another possibility for the retarding effect on PPL release is the increasing film viscosity with increasing SLS concentration; however, further investigations are required to explain this effect.

Benzalkonium chloride (BZK) was used to check the effect of cationic surfactants on PPL release. Concentrations of 2.5 and $5 \%$ BZK showed an increase in the drug release (56.4 and $60.6 \%$, respectively), after 8 hours compared to chitosan film without enhancer (51.2 \%). Wells and Parrott (14) suggested that this surfactant may lower the interfacial tension between the product and the dissolution fluid; hence, it may contribute to the increase in drug release from the prepared film.

In contrast, the concentration of the non-ionic surfactant, Tween 80 , caused significant $(p<0.05)$ PPL release from chitosan films (in the order: $5>2.5>1 \%$ ), as shown in Fig. 1. This is probably due to the reduction in surface tension of the dissolution medium, which allows more rapid release of PPL from the film. Moreover, the addition of oleic acid (OA) of 1 and $5 \%(m / m)$ led to a significant increase in the release of PPL $(p<$ 0.05 and $p<0.001$ respectively, Fig. 1d). The increase in release could be correlated to the increase in MUC of the film matrix as a function of OA concentration.

\section{In vitro skin permeation}

Regression analysis of the obtained results showed that the Higuchi model gave the highest value of $R^{2}$ with a significant difference $(p<0.05)$ compared to other kinetic models. Therefore, the Higuchi model was found to be a most suitable model to describe the permeation kinetics of PPL from the film preparations examined in the present study. The Higuchi rate constant was calculated and is summarized in Table IV.

Table III. Bioadhesive strength of chitosan films

\begin{tabular}{lcc}
\hline \multicolumn{1}{c}{ Sample } & $\begin{array}{c}\text { Adhesiveness } \\
(\mathrm{g})^{\mathrm{a}}\end{array}$ & $\begin{array}{c}\text { Work of adhesion } \\
(\mathrm{g} \mathrm{cm})^{\mathrm{a}}\end{array}$ \\
\hline Blank film $(2 \%, \mathrm{~m} / \mathrm{m}$ chitosan) & $63.6 \pm 5.6$ & $12.9 \pm 9.1$ \\
Control film $\left(2 \mathrm{mg} \mathrm{cm}{ }^{-2} \mathrm{PPL}, 2 \%, \mathrm{~m} / \mathrm{m}\right.$ chitosan) & $62.5 \pm 4.3$ & $12.6 \pm 3.2$ \\
$\begin{array}{l}\text { Candidate film }\left(\mathrm{PPL} 2 \mathrm{mg} \mathrm{cm}^{-2} \text {, chitosan } 2 \% \mathrm{~m} / \mathrm{m},\right. \\
\text { cineole } 10 \%, \mathrm{~m} / \mathrm{m})\end{array}$ & $60.6 \pm 2.9$ & $12.5 \pm 2.3$ \\
\hline
\end{tabular}

a Mean $\pm \mathrm{SD}, n=5$.

Work of adhesion is defined as of the attraction between phases per unit area being in contact with each other $(\mathrm{g} \mathrm{cm})(15)$. 
B. K. A. Rasool et al.: Design and evaluation of a bioadhesive film for transdermal delivery of propranolol hydrochloride, Acta Pharm. 61 (2011) 271-282.

Table IV. Higuchi's permeation rate constant $(\mathrm{k}) \pm S D$ and coefficient of determination $\left(\mathrm{R}^{2}\right)$ of the PPL-chitosan film preparations

\begin{tabular}{|c|c|c|}
\hline Formula & $k\left(\mu \mathrm{g} \mathrm{h}^{-1 / 2}\right)^{\mathrm{a}}$ & $R^{2}$ \\
\hline PPL $\left(1 \mathrm{mg} \mathrm{cm}^{-2}\right)$ & $47.73 \pm 1.88$ & 0.892 \\
\hline PPL (2 $\mathrm{mg} \mathrm{cm}^{-2}$, control) & $97.56 \pm 2.65$ & 0.911 \\
\hline PG (5 \%) & $213.25 \pm 3.80$ & 0.979 \\
\hline PG $(10 \%)$ & $107.75 \pm 1.56$ & 0.912 \\
\hline PG (15\%) & $87.04 \pm 5.98$ & 0.839 \\
\hline Cineol (5\%) & $226.61 \pm 3.98$ & 0.998 \\
\hline Cineole $(5 \%+$ PG $10 \%)$ & $230.15 \pm 1.88$ & 0.991 \\
\hline Menthol (5\%) & $130.03 \pm 1.27$ & 0.985 \\
\hline Menthol (5 \% + PG $10 \%)$ & $164.05 \pm 8.76$ & 0.989 \\
\hline Cineol $(10 \%)$ & $379.92 \pm 4.23$ & 0.996 \\
\hline Cineole (10 \% + PG $10 \%)$ & $296.02 \pm 1.21$ & 0.932 \\
\hline Menthol (10\%) & $175.21 \pm 6.61$ & 0.837 \\
\hline Menthol (10\% + PG $10 \%)$ & $280.33 \pm 1.32$ & 0.902 \\
\hline SLS (1 \%) & $185.91 \pm 1.72$ & 0.994 \\
\hline SLS $(2.5 \%)$ & $221.49 \pm 4.32$ & 0.972 \\
\hline SLS (5 \%) & $239.71 \pm 3.51$ & 0.990 \\
\hline Tween $80(5 \%)$ & $273.19 \pm 8.75$ & 0.997 \\
\hline Tween $80(2.5 \%)$ & $215.45 \pm 7.97$ & 0.967 \\
\hline Tween $80(1 \%)$ & $182.91 \pm 4.98$ & 0.932 \\
\hline BZK (1 \%) & $114.75 \pm 6.94$ & 0.981 \\
\hline BZK $(2.5 \%)$ & $134.28 \pm 1.39$ & 0.948 \\
\hline BZK (5 \%) & $246.21 \pm 7.56$ & 0.938 \\
\hline OA $(1 \%)$ & $114.02 \pm 1.93$ & 0.897 \\
\hline $\mathrm{OA}(5 \%)$ & $310.33 \pm 7.95$ & 0.990 \\
\hline
\end{tabular}

a Mean $\pm \mathrm{SD}, n=3$.

Skin permeation of PPL significantly increased $(p<0.05)$ via increasing the loading concentration of PPL in the prepared chitosan films (Table IV). This may be due to the fact that the loading of PPL of $2 \mathrm{mg} \mathrm{cm}^{-2}$ tended to thicken the film and significantly enhance the capacity of moisture uptake.

Results showed that PG $5 \%(m / m)$ significantly increased $(p<0.05)$ the permeation rate constant of PPL (Table IV). However, when the concentration of PG increased to 10 and $15 \%(\mathrm{~m} / \mathrm{m})$ in the film, a non-significant decrease in the permeation profile was observed. For PG $5 \%(\mathrm{~m} / \mathrm{m})$, the enhancement is possibly due to the increase in the solublizing ability of the aqueous site in the stratum corneum considered to be the main probable mechanism of increasing skin permeation for PG. 
Chitosan films containing terpenes $10 \%$ generally gave significantly higher $(p<0.05)$ permeation enhancement of PPL than $5 \%$ concentrations, which is acceptable since the effect of permeation enhancers often depends on their concentration.

Terpenes significantly increased penetration of PPL in the following order: cineole and PG > menthol and PG > menthol $10 \%$. However, a highly significant effect $(p<$ $0.001)$ was obtained with cineole $10 \%(\mathrm{~m} / \mathrm{m})$ alone (Table IV). The possible mechanism for cineole having the highest enhancing property among other terpenes, as suggested by Barry and Williams (15), is that cineole would interact with the lipid component of the stratum corneum more easily because its boiling point was lower than that of other terpenes and the low boiling point is an indication of weak cohesiveness or self association, which might explain why cineole showed the highest enhancing effect on skin permeation of PPL.

Although the increment in SLS concentrations did not significantly enhance in vitro release of PPL, a raise in SLS concentration to $5 \%(\mathrm{~m} / \mathrm{m})$ resulted in a significant increase $(p<0.05)$ in PPL rat skin permeation (Table IV). It has been reported that an anionic surfactant, like SLS, can penetrate and interact strongly with the skin, producing considerable alterations in the barrier properties. For the non-ionic surfactant Tween 80, the highest permeation was observed with the film containing a concentration of $5 \%$ $(m / m)(p<0.05)$ (Table IV). One of the possible mechanisms for the non-ionic surfactants enhancement is that surfactant may penetrate into the intercellular region of the stratum corneum, increasing fluidity and eventually solubilizing and extracting lipid components.

BZK produced the highest permeation at a concentration of $5 \%(p<0.05)$ (Table IV). High concentration of BZK caused extensive damage to the skin and consequently increased the PPL permeation profile.

On the other hand, OA $1 \%$ seemes to have greater effect on permeation of PPL and the permeation is significantly increased $(p<0.05)$ compared to OA $5 \%$. This may be due to slowed down drug partitioning into the stratum corneum using a large amount of OA. Previous studies have reported that OA-induced skin penetration enhancement results from a mechanism involving both stratum corneum lipid fluidization and lipid phase separation, with the latter likely to predominate.

\section{CONCLUSIONS}

To avoid extensive first-pass elimination and achieve the desirable transdermal penetration rate of PPL, we have prepared polymeric film formulations for transdermal use by employing chitosan as a film former, glycerin as a plasticizer and different types of penetration enhancers. The film containing propranolol $\cdot \mathrm{HCl} 2 \mathrm{mg} \mathrm{cm}^{-2}$, chitosan $2 \%$ and cineole $10 \%$ successfully improved the skin penetration of PPL. Also, the candidate film preparation was non irritant to the skin and was quite promising for safely achieving the desirable systemic absorption of PPL.

Acknowledgements. - The authors gratefully acknowledge financial support of the College of Pharmacy, University of Baghdad, Baghdad, Iraq. 
B. K. A. Rasool et al.: Design and evaluation of a bioadhesive film for transdermal delivery of propranolol hydrochloride, Acta Pharm. 61 (2011) 271-282.

\section{REFERENCES}

1. T. Kimura and K. Higaki, Gastrointestinal transit and drug absorption, Biol. Pharm. Bull. 25 (2002) 149-164; DOI: 10.1248/bpb.25.149.

2. K. Higaki, C. Amnuaikit and T. Kimura, Strategies for overcoming the stratum corneum: chemical and physical approaches, Am. J. Drug Deliv. 1 (2003) 187-214.

3. T. Sawamoto, S. Haruta, Y. Kurosaki, K. Higaki and T. Kimura, Prediction of plasma concentration profile of orally administered drugs based on gastrointestinal transit kinetics and absorbability in rats, J. Pharm. Pharmacol. 49 (1997) 450-457.

4. J. K. Kou, Transport in Polymer Systems, in Transport Processes in Pharmaceutical Systems (Ed. G. L. Amidon), Marcel Dekker, New York 2000, pp. 445-471; DOI: 10.1201/9780203909478.ch12.

5. H. Schaefer and T. E. Redelmeier, Structure and Dynamics of the Skin Barrier, in Skin Barrier: Principles of Percutaneous Absorption, Karger, Basel 1996, pp. 1-42.

6. M. Kitahara, F. Ishiguro, K. Takayama, K. Isowa and T. Nagai, Evaluation of skin damage of cyclic monoterpenes, percutaneous absorption enhancers by using cultured human skin cells, Biol. Pharm. Bull. 16 (1993) 912-916.

7. K. K. Peh and C. F. Wong, Polymeric film as vehicle for buccal delivery: Swelling, mechanical and bioadhesive properties, J. Pharm. Pharm. Sci. 2 (1999) 53-61.

8. C. Amnuaikit, I. Ikeuchi, K. Ogawara, K. Higaki, Kazutaka and T. Kimura, Skin permeation of propranolol $\mathrm{HCl}$ from polymeric film containing terpene enhancers for transdermal use, Int. J. Pharm. 289 (2005) 167-178; DOI: 10.1016/j.ijpharm.2004.11.007.

9. United States Pharmacopoeia 24/National Formulary 19, USP Convention, Rockville 2000, p. 2235.

10. T. Higuchi, Mechanism of sustained action medication. Theoretical analysis of rate of release of solid drugs dispersed in solid matrices, J. Pharm. Sci. 52 (1963) 1145-1149; DOI: 10.1002/jps. 2600521210.

11. Standard Practice for Testing Biomaterials in Rabbits for Primary Skin Irritation, A.S.T.M. Designation F 719-81, American Society for Testing and Materials, Philadelphia 1998, pp. 178-179.

12. S. A. Yehia, O. N. El-Gazayerly and E. B. Basalious, Fluconazole mucoadhesive buccal films: in vitro/in vivo performance, Current Drug Deliv. 6 (2009) 17-27; DOI: 10.2174/156720109787048195.

13. G. Yang, N. Jain and S. H. Yalkowsky, Combined effect of SLS and (SBE) 7M- $\beta-C D$ on the solubilization, Int. J. Pharm. 269 (2004) 141-148; DOI: 10.1016/j.ijpharm.2003.09.001.

14. M. L. Wells and E. L. Parrott, Effect of surfactants on release of a highly water-soluble medicinal compound from an inert, heterogeneous matrix, J. Pharm. Sci. 81 (1992) 453-457; DOI: 10.1002/ jps.2600810513.

15. B. W. Barry and A. C. Williams, Human skin penetration enhancement: the synergy of propylene glycol with terpenes, Proc. Int. Symp. Control. Rel. Bioact. Mater. 16 (1989) 33-34. 
B. K. A. Rasool et al.: Design and evaluation of a bioadhesive film for transdermal delivery of propranolol hydrochloride, Acta Pharm. 61 (2011) 271-282.

\section{Dizajniranje i vrednovanje bioadhezijskog filma za transdermalnu isporuku propranolol hidroklorida}

BAZIGHA K. ABDUL RASOOL, UDAY S. AZIZ, OMAR SARHEED i ALAA A. ABDUL RASOOL

Cilj rada bio je razvoj pogodnog transdermalnog sustava na bazi kitozana za isporuku propranolol hidroklorida (PPL). Svim pripravcima ispitana je jednoličnost udjela lijeka, debljina, sposobnost vlaženja i bioadhezivnost na kožu. Ispitivan je i utjecaj kitozana, koncentracije PPL-a i sredstva za povećanje permeacije na oslobađanje i permeacijski profil, te potencijalni iritacijski učinak na kožu. Iz kitozanskog filma (PPL $2 \mathrm{mg} \mathrm{cm}{ }^{2}$, $2 \%, m / m$, kitozana i $10 \%, m / m$, cineola), koji nije djelovao iritabilno, postignuto je $88,2 \%$ oslobađanja nakon 8 sati u fosfatnom puferu. S ovim pripravkom postignuta je i vrlo značajna $(p<0,001)$ permeacija PPL kroz kožu štakora, oko osam puta veća u usporedbi s filmom bez sredstva za povećanje permeacije. Pripravak bi se mogao upotrijebiti za transdermalnu isporuku PPL.

Ključne riječi: transdermalna isporuka, propranolol hidroklorid, kitozanski film, sredstvo za povećanje permeacije 